\title{
Referaat
}

\section{Slechtnieuwsgesprekken voeren: een lastige klus}

\author{
Dosanjih S, Barnes J, Bhandari M. Barriers to \\ breaking bad news among medical and surgi- \\ cal residents. Med Educ 2001;35:197-205.
}

Een 'slechtnieuwsgesprek' voeren met patiënten en hun familie kan moeilijk zijn. Dosanjih en medeauteurs onderzochten welke barrières specialisten-in-opleiding ervaren bij het brengen van slecht nieuws aan patiënten en hun familie. Aan het onderzoek werd deelgenomen door twee focusgroepen: een groep van zeven en een groep van acht eerste- en tweedejaars specialisten-in-opleiding afkomstig van verschillende disciplines. Bij de vijftien deelnemers werd een anderhalf uur durend semi-gestructureerd interview afgenomen. Deze interviews werden woordelijk uitgeschreven, gecodeerd en geanalyseerd volgens de procedure van de 'grounded theory'. De resultaten werden vervolgens ingedeeld in drie categorieën: kennis van strategieën om slecht nieuws te brengen, de barrières die men tegenkomt bij het voeren van een slechtnieuwsgesprek en maatregelen die kunnen leiden tot een beter verloop van slechtnieuwsgesprekken.

Kennis van strategieën (richtlijnen) om slecht nieuws te brengen

Wat de verbale aspecten betreft is men veelal op de hoogte van de algemene richtlijnen hiervoor. De ondervraagde specialisten-in-opleiding zijn het erover eens dat de non-verbale communicatie zeer belangrijk is, zoals tijd nemen, gaan zitten, et cetera. Het bieden van steun aan de patiënt en de familie nadat het slechte nieuws gebracht is, wordt als zeer moeilijk ervaren.

De ideeën van de participanten over persoonlijke en met de ziekenhuisomgeving samenhangende factoren die een barrière vormen bij het brengen van slecht nieuws

Als eerste punt wordt het verschil genoemd tussen patiënt en arts in wat men als slecht nieuws ervaart. Dit wordt bepaald door subjectieve factoren en de rol die men vervult in de communicatie. Het maakt verschil of men de brenger of de ontvanger van slecht nieuws is. De specialisten-in-opleiding ervaren stress bij het brengen van slecht nieuws. Ze zijn vaak bang dat patiënten hen niet (voldoende) empathisch vinden. Veelgenoemde barrières die samenhangen met de ziekenhuisomgeving zijn tijdgebrek en onvoldoende steun van collega's, supervisors en andere hulpverleners.

Mogelijkheden die geboden zouden kunnen worden om slechtnieuwsgesprekken beter te laten verlopen

De specialisten-in-opleiding vragen meer training met daarin een duidelijk onderscheid tussen het brengen van slecht nieuws in een acute of chronische setting. Op het gebied van ondersteuning spreekt men voorkeur uit voor een team-aanpak bij het brengen van slecht nieuws. Er zou bijvoorbeeld ook een verpleegkundige of sociaal werker bij het gesprek aanwezig kunnen zijn.

In de discussie stellen de auteurs dat specialisten-in-opleiding wel op de hoogte zijn van de algemene richtlijnen voor het brengen van slecht nieuws, maar dat de toepassing daarvan belemmerd wordt door persoonlijke en omgevingsfactoren. Gebrek aan tijd en ondersteuning zullen de persoonlijke barrières nog zwaarder doen wegen, omdat er geen gelegenheid is om stil te staan bij de eigen emoties.

In onze westerse, traditionele medische opleidingen ligt de nadruk vooral op het biochemisch paradigma. Het lichaam wordt gezien als een compilatie van verschillende onderdelen en de specialist behandelt één van die onderdelen. Patiënten vragen echter een holistische benadering, waarbij biomedische en psychosociale aspecten geïntegreerd worden. Dit vereist een paradigmawijziging. Op die manier zal de kwaliteit van de zorg verbeteren, stellen de onderzoekers. Daarvoor is effectieve training in communicatievaardigheden noodzakelijk, ook op het gebied van slechtnieuwsgesprekken. 
We zouden kunnen denken dat de in het artikel geschetste problematiek in onze contreien niet voorkomt, omdat de medische studenten in Nederland en stilaan ook in België meer communicatietraining ontvangen dan voorheen. Toch blijkt uit onderzoek dat patiënten steeds vaker klagen over de communicatie met hun artsen. Deze vaststelling is belangrijk en vraagt mijns inziens om diepgaand onderzoek.

J.P.M. Denekens

Antwerpen 